PROCEEDINGS OF THE WORLD CONFERENCE ON OZONE THERAPY IN MEDICINE, DENTISTRY AND VETERINARY. ANCONA (ITALY). SEPTEMBER 22nd - 23rd - 24th, 2017

\title{
Evaluation of Ozone Therapy as adjuvant therapy in cancer patients and reduction of side effects of Radiation therapy - Indian experiences [abstract]
}

\author{
Mili Shah ${ }^{1}$, Arvind Kulkarni² \\ 'Ozone Forum of India, 2Radiation Department, Lady Ratan Tata Medical Centre, Mumbai, India.
}

\section{ABSTRACT}

\section{OPEN ACCESS}

\section{Citation}

Shah M, Kulkarni A. Evaluation of Ozone Therapy as adjuvant therapy in cancer patients and reduction of side effects of Radiation therapy- Indian experiences [abstract]. Proceedings of The World Conference on Ozone Therapy in Medicine, Dentistry and Veterinary. Ancona (Italy). September 22nd - 23rd - 24th , 2017. J Ozone Ther. 2019;3(4):58-59. doi: 10.7203/ jo3t.3.4.2019.15540

Academic Editor

Jose Baeza-Noci,

School of Medicine, Valencia

University, SPAIN

\section{Editor}

World Federation of Ozone Therapy, Bolgna, ITALY

\section{Received}

June 17, 2019

\section{Accepted}

December 08, 2019

Published

December 30, 2019

Intellectual Property

Mili Shah.

This is an open access article distributed under the terms of the Creative Commons Attribution License (CC BY 4.0), which permits unrestricted use, distribution, and reproduction in any medium, provided the original author and source are credited.

\section{Author Information} drmilishah@gmail.com
Purpose. India is new cancer capital of world with almost one third of cases registered from India, In this century, cancer is projected to be the leading cause of death. Neoplasia is a multifactorial process that can be broadly categorized into five etiologies: genetic, viral, chemical, physical and inflammatory. Chemical, physical and inflammatory are closely linked to reactive oxygen species (ROS), which can readily induce genomic damage. Although the precise mechanisms responsible for increased ROS stress in cancer cells have not be defined, the increase in ROS generation is attributed to active cellular metabolic activity under the influence of oncogenic signals and/or to mitochondrial malfunction in cancer cells.

Ozone therapy (OT) biological effects are: cellular redox balance (OT can exert its protective effects by means of an oxidative preconditioning, stimulating and/or preserving the endogenous antioxidant systems); regulation of the immunological system, increase of prostacyclin, as well as the increase of oxygenation in tumours.

Tumour Hypoxia is a well-recognized mechanism for resistance of neoplastic cells to anticancer drugs and radiation.

Material and Methods. The clinical trial included only 83 patients with mainly oral, breast and brain cancer patients in treatment with cobalt-60 therapy at Lady Ratan Tata Memorial Radiation Department were also treated with Rectal Insufflation of an ozone-oxygen at a dose of $7 \mathrm{mg}$ $(200 \mathrm{~mL}$ at $35 \mathrm{mcrg} / \mathrm{mL}), 6$ days per week along with Minor auto haemotherapy $(100 \mathrm{mcrg})$ alternatively for 6 weeks till the duration radiotherapy.

Results. The appearance of side effects (dermatitis, pigmentation, ulceration) minimized to $24 \%$ in the ozone group that means a significant difference post radiation. When compared to patients not treated with OT. One month after finishing the treatment, with significant difference in patients supported by OT. The clinical observation were:

- Improvement in Energy Level

- Feeling of Cheerfulness

- Improved Appetite

- Improved WBC, RBC and Hb levels

- Reduction in Tumor Markers, CEA, AFP, CA125 
Conclusion. OT is effective as adjuvant to conventional approach of Radiation in reducing side effects of radiation by improvement of blood circulation and oxygen delivery to ischemic and neoplastic tissues. Furthermore, it correct the chronic oxidative stress by upregulating the antioxidant system procuring a state of well-being in patients by activating the neuro-endocrine system.

\section{References}

1. Bocci V. Oxygen-Ozone Therapy. A Critical Evaluation. Dordrecht (NL): Kluwer Academic Publishers; 2002. 440 p. ISBN: 9789401599528.

2. Viehban-Hansler, R., Fernandez O., Fahmi Z, Ozone in Medicine: The Low Dose Concept - Guidelines and Treatment Strategies, Ozone Sci Eng. 2012;34:408-424.

3. Viehban-Hansler R. The Use of Ozone in Medicine, 5th edition.

4. Iffezheim: ODREI Pub; 2007.

5. Bocci V. Ozone. A new medical drug. Dordrecht (NL): Springer; 2005. 324 p. ISBN: 9789048192342. 